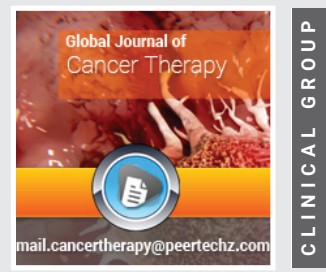

\title{
Modern applications of cryosurgery in oncology
}

\author{
Karthikeyan $\mathrm{M}^{1 *}$, Deepa $\mathrm{MK}^{1 *}$, Balasubramanian $\mathrm{T}^{2}$, \\ Monika Reji ${ }^{2}$, Satish RC ${ }^{1}$, Abhay AD ${ }^{1}$, Shruti PC $^{1}$ and Omkar \\ $\mathrm{SD}^{1}$
}

${ }^{1}$ Ashokrao Mane College of Pharmacy, Pethvadgaon, Kolhapur, Maharashtra 416112, India

${ }^{2}$ Al Shifa college of Pharmacy, Kizhatur, Malappuram Dist, Kerala 679325, India

Check for updates

Received: 30 April, 2020

Accepted: 18 May, 2020

Published: 19 May, 2020

*Corresponding author: Dr.Karthikeyan M, Associate professor, Department of Pharmacology, Ashokrao Mane College of Pharmacy,Pethvadgaon,Kolhapur, Maharashtra 416112, India, Tel: 9656111669; E-mail: karthikeyanpgt@gmail.com

Keywords: Cryosurgery; Freezing; Mechanism of freezing injury; Cooling; Dermatology; Tumor; Cancer https://www.peertechz.com

\begin{abstract}
Cryosurgery techniques has been used in the ancient period. Cryosurgery employs the high rate of freezing rate to destroy the undesirable tissues. The cryosurgery techniques is a minimal invasive techniques applied in various clinical aspects. The cryosurgery techniques has advantages over the normal surgical procedures. It has high cure rate in some disease states. Development of the cryosurgery is in slow manner due to the lack of clear knowledge of the techniques. The Cryosurgery has to be expanded to the all the clinical aspects with better understanding and better curing of the diseases.
\end{abstract}

\section{Introduction}

Cancer a diseases that cause cells in the body to change and loos the control. Most of the types of cancer cells form a mass called a tumor. Breast Cancer is a type of cancer that begins in the breast. Most breast cancers begin in the breast tissue made up of glands called lobules and the ducts that connect the lobules to the nipple. The remainder of the breast is made up of fatty, connective, and lymphatic tissues [1]. Breast cancer is the most common cancer in US women and is the second leading cause of cancer death among women. In 2019, an estimated 268,600 new cases of invasive breast cancer will be diagnosed among women. More than 3.8 million US women with a history of breast cancer were alive as per the survey report on January 1, 2019. More than 150,000 breast cancer survivors are living with metastatic disease, three-fourths of whom were originally diagnosed with stage I-III [2]. Even though there are various treatment options like Systemic therapy, Surgery, Radiation therapy, Chemotherapy: Hormonal therapy, Targeted therapy and Immunotherapy. The modern cryosurgery technology give complete cure.

\section{Cryosurgery technology}

Cryosurgery technology has made great strides in the last few years. Cryosurgery is a potential alternative for the various disease treatment due to the resulting changes that occur to tissues during and after the freeze-thaw process and initial clinical results. Cryosurgery being established as a primary in situ therapy for breast cancer and also to various other diseases. Modern Technological advancements of cryosurgery technology, advances in ultrasound technologies that allow accurate real time visualization of the cryosurgical process [3].

\section{Brief history of cryosurgery}

In $11^{\text {th }}$ century, 980-1037 Cold is used for anesthetic property [4]. Hippocrate stated that the use of cold water in an acute gout attack was used with success on himself [5], in 1650. In 16th century, 1661 effect of cold as an anaesthetic [6]. In Russian campaign cold and snow applied to reduce pain and haemorrhage. During the Russian campaign the temperature below $-50^{\circ} \mathrm{C}$, the effect of cold has a sedative effect on the brain and nervous system.in 1777 cold showed the destructive effect when used in the treatment of tumours. [7-10] In 1851 so many studies has been conducted on cold or ice and it applications as anesthetic and in cancer at $-12^{\circ} \mathrm{C}$ to $-55^{\circ} \mathrm{C}$. In 1882 Paris, use extreme cold as produced by methyl chloride to treat tumours [11]. In 1833 ice cold water is used to treat chronic cervicitis. In 19th century, certain tumours are treated by freezing,the effects of cold have been used in medicine for a very long time. The term "cryo" is used incorrectly in 
medicine as it really implies all temperatures below $-153^{\circ} \mathrm{C}$. In 1907 liquid air is used treat vascular lesions. In 1930 liquid air used at $-182.9^{\circ} \mathrm{C}$ used for acne [12].

\section{Mechanisms of freezing injury}

In 1960 the cryosurgery procedure adopted fast freezing ,slow thawing and repetition of the same cycle were followed. In 1964 Cooper identified the holding the tissue at $200 \mathrm{C}$ for one minute could induce necrosis process [13]. In cryosurgery the tissue has been freeze with a help of cryosurgical probe brought in contact with the abnormal tissue. The probe is cooled due to the circulation of cooling fluid. The probe will deliver the cooling fluid. Within few minutes the cooling begins. The cooling fluid extract the heat from the tissues, though the probe. At that time the frozen tissue has a temperature distribution that ranges from a low cryogenic temperature at the tissue surface in contact with the probe to the phase transformation temperature on the outer edge of the frozen lesion. In the cryosurgical protocols , after freezing ,the frozen tissue is heating and thawing. The frozen tissue is warmed with the help of probe surface by a warming fluid circulating through the cryosurgical probe. Cryosurgery procedure may last to several minutes to an hour. The cell near to the probe surface will be cooled at higher cooling rate and to lower temperature than away from probe.The cell at different locations will be at different temperatures for various period of time. The cell damage during the cooling and freezing can be: Nano scale ,micron scale and macro scale. The damage during cryosurgery can be of two types acute and long term [13-15].

\section{The effect of cooling}

The mammalian cells and human tissues can withstand low and nonfreezing temperatures for short period. The cells with specific intracellular chemical components inside the cell and nonspecific extracellular components outside the cell membrane. The cell plasma membrane selectively permits the chemical components in and out of the cell. The cell membrane acts as a selective barrier between the intracellular and the extracellular milieu. The membrane selectively controls the transport of chemical species into and out of the cell. Therefore, the membrane must be mostly impermeable except at particular sites where it can control the mass transfer. The lipid bilayer of the cell membrane act as a barrier for selectivity. The lipid bilayer is at fluid state during normal temperature. At low temperature the lipid undergoes phase transition into gel phase. During this phase the proteins become segregated and defect form in the proteins and in membrane. The cell membrane are more permeable to ions and chemical components in an uncontrolled way [16-18].

Life process are temperature dependent biochemical reactions process. At low temperature the efficiency of the cell plasma membrane reduces and ability to control the intracellular component. At low temperature intracellular component and ions begins to change the property of ions. The damage will be in huge. The cytoskeleton chemical bonds with the plasma proteins will be weakens and make them fragility to mechanical damage. The denaturation of proteins due to change in the intracellular ion and temperature. Most of the cell can withstand the cool temperature above the freezing but it depends on the time scale in the cryosurgery process. The major exceptions are the cell that are highly sensitive to the ions are platelets ,during cooling the platelets allows the influx of calcium and it appears to trigger activation of platelets. This cascade of process will end in the platelet aggregation and this leads to obstruction of blood vessels in the cooled region. Meiotic spindles are sensitive to hypothermia, resulting in depolymerization. oocytes cooled to $0^{\circ} \mathrm{C}$ for $2 \mathrm{~min}$ to $3 \mathrm{~min}$, the meiotic spindle cooled at $0^{\circ} \mathrm{C}$ for $3 \mathrm{~min}$ are shortened and disappeared [18-19].

\section{The effect of freezing}

During freezing for cryopreservation is different from the thermal process in cryosurgery. In cryopreservation the cells are frozen in vitro ,they are uniformly frozen in same condition to very low temperatures and kept in the frozen state for long period of time. Freezing of cells process begins in the extracellular milieu and the interior of the cell in unfrozen. The cells experience in the hypertonic solutions, between ice crystals. The lower the temperature, the extra cellular concentration increases, cell shrinks. The shrinkage in caused by the fact that the unfrozen and super cooled relative to the extracellular fluid, which is in the thermodynamic equilibrium in the ice $[20,21]$. The cells frozen to different subzero temperature the percentage of damaged cells increases gradually (Figure 1). This constitute the hypertonic extracellular solution mechanism of damage, as the hypertonic extracellular concentration increases gradually with decrease in temperature $[20,22]$ Figure 1.

Various research studies has been performed to clear understand the effect of freezing the tissue. One of the hypothesis is the direct cellular injury . The cell injury occurs after the freezing result from high solute concentration causing cell dehydration $[22,23]$. The freezing may lead to

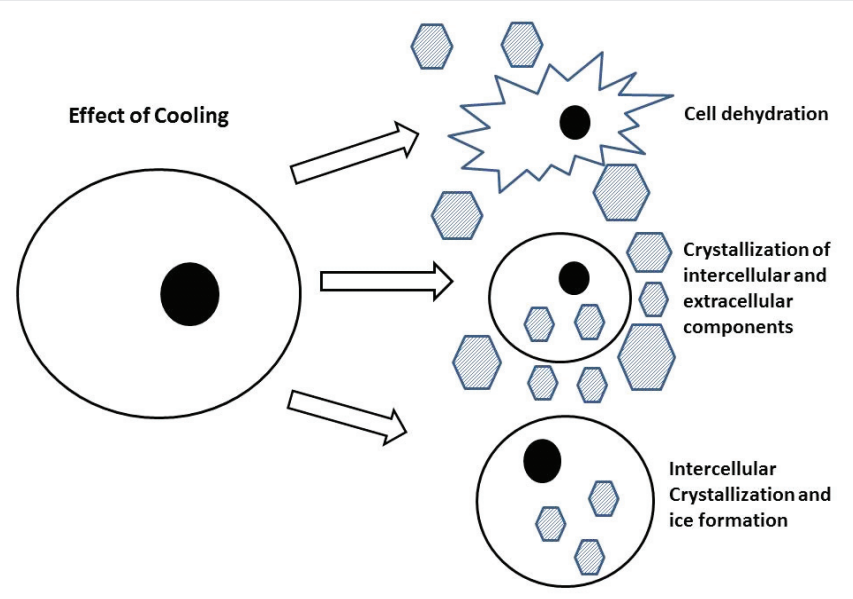

Figure 1: Diagram of the mechanisms of freezing injury. During slow cooling, ice forms in the extracellular space.This leads to cell shrinkage. When the temperature is further decreased, allowing the initiation of eutectic crystallization in the extracellular space. The rapid cooling, the cells are not able to lose water fast enough to maintain equilibrium, resulting in intracellular water becoming supercooled and eventually frozen. Hexagons represent ice crystals. 
intracellular organelle and cell membrane disruption has been implicated. The freezing may stimulate immunological injury. The immune system become sensitized to the destroyed frozen tissue, it leads to the attack. The freezing involves the vascular and connective tissue damage.The freezing results in stasis of blood flow ,which lead to ischemia and to cell necrosis [2426].

\section{Effects of thawing and warming}

Thawing and warming induce cellular damage. During thawing, ice melts, the extracellular solution is hypotonic, causing rupture to the membrane. When thawing is rapid some cells may remain hypertonic at body temperature, which could induce metabolic disruption and additional damage [27]. The effects of thawing depends on the freezing temperature and cooling rate. The slow thawing allows solute to maximum ice growth and recrystallization to take place. The thawing before an another cycle is important in to the success of cryosurgery [28]. The rapid cooling followed by rapid thawing is beneficial. During rapid cooling, the ice crystals tend to be small, with high surface energies. The longer the thawing, the easier the ice to recrystallize, especially crystals with high surface energies. The larger ice crystals can be more destructive than the smaller ones, the size of the crystals and the force generated during recrystallization [29]. During warming, in a frozen state, ice tends to recrytalize at high subzero temparature. Recrytalization will cause further disruption of extracellular and macroscopic structure of the tissue $[30,31]$.

\section{Cryosurgery in breast cancer}

Metastatic breast cancer: Breast cancer is the leading cause of female cancer-related deaths and one of the most common cancers worldwide. Metastasis is the major barrier in breast cancer management, especially at advanced stages. Local manipulations such as radiofrequency ablation (RFA), microwave thermotherapy, cryosurgery (cryotherapy), chemoembolization, radioembolization, breast surgery, or metastasectomy are new emerging strategies for controlling this deadly pathological condition [32]. Percutaneous thermal ablation (PTA) is a choice of local ablative treatment for Radiofrequency ablation methods include oligometastases. PTA, Microwave or cryotherapy ablation, and are small Invasive measures leading to local necrosis To the end of the arrow. PTA represents a safe and successful treatment Modality, particularly for the selected patients. It should have Use multiple times in large lesions, and have Costs lower than with other modalities [32]. With a rapidly expanding variety of oncological uses, PICA is a minimally invasive, secure technique. It is well tolerated, can be used to treat large lesions and does not endanger future oncological therapy [33].

Included 17 female patients (average age 54.8 years \pm 10.8; range 37-72) with primary breast tumor not surgically treated as a result of metastatic diseases. Patients in the time of stable disease were treated for their primary lesion with percutaneous cryotherapy.Using ultrasonic or CT scan guidance, this minimally interference was carried out [34]. The mean main lesion diameter was $16 \pm 12 \mathrm{~mm}$ (size range
5-45 mm). During the follow-up period, we obtained full regression of the primary breast lesion without recurrence in 15 patients. After the operation, all were instantly relaxed and lastingly through all follow-up. These findings indicate that primary breast lesion cryosurgery appears to be well suited for metastatic patients' palliative care, especially due to its good tolerance, low complication rate and ability to provide local or analgesic control [34].

Under CT guidance a single board certified interventional radiologist performed all cryoablation sessions. Percutaneous cryoablation was performed using a cryoablation unit based on the argons. To determine the correct positioning of the tumor ablation probes, both preoperative CT and MRI images were compared. All the procedures were conducted under conscious sedation, using $50 \mu \mathrm{g}$ fentanyl citrate intravenous bolus, and local anesthesia. Vital signs were continuously tracked throughout the entire process. To determine the degree of tumor necrosis, all patients, except three, were tested preoperatively and post-operatively with breast MRI. The mean size for the tumor was $3.02 \pm 1.4 \mathrm{~cm}$. Six patients developed multicenter disease. Complete tumor necrosis at 2-month and 6-month follow-up was 85.7 percent, and 100 percent , respectively, as 5 patients with tumors $>3 \mathrm{~cm}$ required redo cryoablation. No patient had significant complications. During an average 46-month follow-up (range 3-84), 7 patients (20\%) suffered local recurrences treated with redo cryoablation, and $7(20 \%)$ died as a result of disease progression. The findings indicate cryoablation of the primary tumor in the treatment of patients with stage IV breast cancer is safe and reliable [35].

Cryoablation is a safe breast-conserving treatment for Breast Cancer. Achieved excellent rates of local tumor control(90\%), on an average sub optimal local tumor control was noted compared with RF ablation. An advantage of cryoablation over $\mathrm{RF}$ ablations the possibility to perform the procedure under local anesthesia and potentially on an outpatient basis. The best clinical results are achieved when small $(0-15 \mathrm{~mm})$ ductal tumors are treated with an ice ball larger than the tumor [36].

\section{Nipple adenoma}

A 29-year-old woman with a three-year history of serosanguineous intermittent-painless discharge from her left nipple with regular mammography and ultrasound. The patient was diagnosed with nipple adenoma and was confirmed. Cryosurgery is a technique of minimally invasive surgery that stands as a tissue-sparing alternative for this benign condition. The dermoscopic pattern identified by us is unspecified but polymorphic vessels will trigger a biopsy to get a definitive diagnosis. This is the first dermoscopic diagnosis of such condition to our knowledge and the second recorded case of a positive cryosurgical operation [37].

\section{Application of cryosurgery techniques in various clinical aspects}

Dermatology: The application of cryosurgery/cryotherapy in dermatology. The skin cryosurgery requires rapid freezing and slow thawing, minimum tissue temperature of -25 to $-60^{\circ} \mathrm{C}$. Frozen tissue reacts immediately after thawing, followed 
by edema, bulla formation, exudation and mumification. The cryosurgery is used in hypertrophic scars and keloids, granuloma annulare, small capillary infantile hemangioma and isolated actinic keratoses. It is also a valuable alternative therapy for various other skin diseases, warts, solar lentigo, superficial basal cell carcinoma and Kaposi's sarcoma [32].

Breast tumors and cancers: The cryoablation therapies for the treatment of benign breast tumors and small invasive breast cancer. The complete response rate of cryoablation for breast cancer is reported to be relatively good. The cryoablation efficacy is good and safe for breast cancer. Cryoablation also induces an immunomodulatory effect. Cryoablation for primary tumor may enhance the treatment effect of immune checkpoint inhibitors in patients with breast cancer [33].

Ophthalmology: Cryoextractor is employed for clinical use in cataract extraction, likewise in intumescent cataracts and lens subluxation. The utilizing cryoextraction led to reducing the number of complications in ophthalmology. The experiments on rabbits revealed that touching the lens with a wire cooled to $-70^{\circ} \mathrm{C}$ resulted in firm attachment of the lens capsule and subcapsular masses [34].

Oro surgery: Cryosurgery is a method that used to freezing to obtain a tissue inflammatory and/or a destructive response. Its use is increasing for several oral cavity conditions. It shows a very good esthetic and the first choice or an alternative option to conventional surgery [35].

Atrial fibrillation: Atrial Fibrillation results in impaired quality of life and increased mortality. Drugs fail to stabilize sinus rhythm.Catheter ablation of $\mathrm{AF}$ is challenging, decrease the threshold for treatment, broaden the access to the therapy and contribute to further reduction of the disease burden. Cryoenergy is an excellent energy source to combine with a single-shot device, resulting in an excellent safety profile and good clinical results [36-42].

\section{Conclusion}

The use of Cryosurgery techniques has been developed in the ancient period and are still progressing slowly due to the lack of clear knowledge. The mechanism of cryoinjury is complex. The current literature focus on the brief history ,cryosurgery cell injury mechanism and modern use of the cryosurgery in present years. In future the cryosurgery could be used for various clinical aspects and wider usage.

\section{References}

\section{Link: https://bit.ly/2Tkf124}

\section{Link: https://bit.ly/2XgyWQW}

3. Kaufman CS, Rewcastle JC (2004) Cryosurgery for Breast Cancer. Technol Cancer Res Treat 3: 165-175. Link: https://bit.ly/2zSsı1f

4. Bonniot JP (1992) History of cryosurgery. In: Homasson JP., Bell N. (eds) Cryotherapy in Chest Medicine. Springer, Paris 1-5. Link: https://bit.ly/3cVIB5G

5. Aubery J (1949) Brief Lives, William Harvey, Scribner, New York: 231. Link: https://bit.ly/3cW0h1r
6. Bartholini T (1661) De nivis usu medico observationesvariae. Hafniae (Copenhagen) 232. Link: https://bit.ly/2zMWx3q

7. Barnard JDW (1980) The effects of extreme cold on sensory nerve. Ann R Coll Surg Engl 62: 180-187. Link: https://bit.ly/2TmtScy

8. Arnott J (1845) On the present state of therapeutical inquiry. King, Brighton and Churchill, London.

9. Arnott $\mathrm{J}$ (1851) On the treatment of cancer by the regulated application of an anaesthetic temperature. J Churchill, London 32. Link: https://bit.ly/3bLDUKx

10. Arnott $\mathrm{J}$ (1855) On the treatment of cancer by congelation and an improve mode of pressure. J Churchill, London. Link: https://bit.ly/2z0JLyr

11. Lortat-Jacobs L, Solente G (1930) La Cryotherapie. Paris: Masson et Cie.

12. White house $\mathrm{H}$ (1907) Liquid air dermatology : its indications and Limitations. JAMA 49: 371-377. Link: https://bit.ly/2XaL59W

13. Cooper IS (1964) Cryobiology as viewed by the surgeon. Cryobiology 1: 44-54. Link: https://bit.ly/2AH6yzG

14. Cahan W (1965) Cryosurgery of malignant and benign tumors. Fed Proc 24: S241-S248. Link: https://bit.ly/2TIHPYd

15. Gill W, Frazer J, Carter D (1968) Repeated freeze-thaw cycles in cryosurgery. Nature 219: 410-413. Link: https://bit.ly/2XcVD8v

16. Quinn PJ (1985) A lipid phase separation model of low temperature damage to bio- logical membranes. Cryobiology 22: 128-147. Link: https://bit.ly/2WK2JCr

17. McGrath JJ (1988) Membrane transport properties. In Low Temperature Biotech- nology: Emerging Applications and En- gineering Contributions, ed. JJ McGrath, KR Diller, 273-321 New York: ASME. 380.

18. Wolfe J, Bryant G (1999) Drying and/or vitrfication of membrane-solute-water sys- tems. Cryobiology 39: 103-129. Link: https://bit.ly/2WHIS6C

19. Zenzes MT, Bielecki R, Casper RF, Leibo SP (2001) Effects of chilling to 0 degrees $\mathrm{C}$ on the morphology of meiotic spindles in human metaphase II oocytes. Fertil Steril 75: 769-777. Link: https://bit.ly/2za1V0C

20. Mazur P (1970) Cryobiology: the freezing of biological systems. Science 68: 939-949. Link: https://bit.ly/2TjWKSG

21. Ishiguro H, Rubinsky B (1994) Mechan- ical interactions between ice crystals and red blood cells during directional solidifi- cation. Cryobiology 31: 483-500. Link: https://bit.ly/36bkNs9

22. Lovelock JE (1953) The haemolysis of human red blood cells by freezing and thawing. Biochem Biophys Acta 10: 414-4 26. Link: https://bit.ly/2LHcqek

23. Steponkus PL (1984) Role of the plasma membrane in freezing injury and cold acclimation. Ann Rev Plant Physiol 35: 543-584.

24. Ablin RJ (1995) An appreciation and realization of the concept of cryoimmunology. In: Onik G, Rubinsky B, Watson G, et al, eds. Percutaneous Prostate Cryoablation. St Louis: Quality Medical Publishing 136.

25. Hoffmann NE, Coad JE, Huot CS, Swanlund DJ, Bischof JC (2001) Investigation of the mechanism and the effect of cryoimmunology in the Copenhagen rat. Cryobiology 42: 59-68. Link: https://bit.ly/3cLEMQv

26. Fraser J, Gill W (1967) Observations on ultra-frozen tissue. Br J Surg 54: 770776. Link: https://bit.ly/2zcEeoh

27. Gage AA, Baust J (1998) Mechanisms of tissue injury in cryosurgery. Cryobiology 37: 171-186. Link: https://bit.ly/3dZn0K2

28. Gage AA, Guest K, Montes M, Caruana JA, Whalen DA (1985) Effect of varying freezing and thawing rates in experimental cryosurgery. Cryobiology 22: 175182. Link: https://bit.ly/2WJQKow 
29. Mazur P (1984) Freezing of living cells: Mechanisms and implications. Am J Physiol 247: C125-C142. Link: https://bit.ly/2zLSvbl

30. Whitaker D (1978) Electron microscopy of the ice crystals formed during cryosurgery: relationship to duration of freeze. Cryobiology 15: 603-607. Link: https://bit.ly/3dZps2W

31. Merryman HT, (1966) Cryobiology. New York: Academic. 966 pp.

32. Tian Q, Wang Y, Guo H, Xie G, Li J, et al. (2017) Recent perspectives of management of breast cancer metastasis - an update. J BUON 22: 295-300. Link: https://bit.ly/2TisZlb

33. Cazzato RL, Garnon J, Ramamurthy N, Koch G, Tsoumakidou G, et al. (2016) Percutaneous image-guided cryoablation: current applications and results in the oncologic field. Med Oncol 33: 140. Link: https://bit.ly/3fZBPOI

34. Beji H, Pilleul F, Picard R, Tredan O, Bouhamama A, et al. (2018) Percutaneous cryoablation of breast tumours in patients with stable metastatic breast cancer: safety, feasibility and efficacy. $\mathrm{Br} J$ Radiol 91: 20170500. Link: https://bit.ly/2TdBX39

35. Pusceddu C, Melis L, Ballicu N, Meloni P, Sanna V, et al. (2017) Cryoablation of Primary Breast Cancer in Patients with Metastatic Disease: Considerations Arising from a Single-Centre Data Analysis. Biomed Res Int 2017: 1-8. Link: https://bit.ly/2Tmw8k2
36. Lanza E, Palussiere J, Buy X, Grasso RF, Beomonte Zobel B, et al. (2015) Percutaneous Image-Guided Cryoablation of Breast Cancer: A Systematic Review. J Vasc Interv Radiol 26: 1652-1657.e1. Link: https://bit.ly/2Wlu8o7

37. Pasquali P, Freites-Martinez A, Fortuño A (2016) Nipple Adenoma: New Images and Cryosurgery Treatment. Breast $\mathrm{J}$ 22: 584-585. Link: https://bit.ly/2TiUKKx

38. Zouboulis CC (2015) Kryochirurgie in der Dermatologie Cryosurgery in dermatology. Hautarzt. 66: 834-848. Link: https://bit.ly/2X7WsiR

39. Takada M, Toi M (2019) Cryosurgery for primary breast cancers, its biological impact, and clinical outcomes. Int J Clin Oncol 24: 608-613. Link: https://bit.ly/2WHi4U8

40. Grzybowski A, Kanclerz P (2019) The inventor of cryosurgery in ophthalmology. Eur J Ophthalmol 29: 348-356. Link: https://bit.ly/2zPwqZy

41. Bansal A, Jain S, Gupta S (2012) Cryosurgery in the treatment of oro-facial lesions. Indian J Dent Res 23: 297. Link: https://bit.ly/2ThE462

42. Hintringer $F$ (2016) Cryoablation of atrial fibrillation. Br Med Bull 120: 101-109. Link: https://bit.ly/36a1gYW

\section{Discover a bigger Impact and Visibility of your article publication with}

\section{Peertechz Publications}

\section{Highlights}

* Signatory publisher of ORCID

- Signatory Publisher of DORA (San Francisco Declaration on Research Assessment)

- Articles archived in worlds' renowned service providers such as Portico, CNKI, AGRIS, TDNet, Base (Bielefeld University Library), CrossRef, Scilit, J-Gate etc.

* Journals indexed in ICMJE, SHERPA/ROMEO, Google Scholar etc.

* OAI-PMH (Open Archives Initiative Protocol for Metadata Harvesting)

* Dedicated Editorial Board for every journal

* Accurate and rapid peer-review process

* Increased citations of published articles through promotions

* Reduced timeline for article publication

Submit your articles and experience a new surge in publication services (https://www.peertechz.com/submission).

Peertechz journals wishes everlasting success in your every endeavours.

Copyright: (C) 2020 Karthikeyan M, et al. This is an open-access article distributed under the terms of the Creative Commons Attribution License, which permits unrestricted use, distribution, and reproduction in any medium, provided the original author and source are credited.

Citation: Karthikeyan M, Deepa MK, Balasubramanian T, Reji M, Satish RC, et al. (2020) Modern applications of cryosurgery in oncology. Glob J Cancer Ther 6(1): 010-014. DOI: https://dx.doi.org/10.17352/2581-5407.000029 